\title{
APA YANG BERBEDA? KEMAMPUAN KOGNITIF PADA ANAK TUNANETRA TANPA PENGALAMAN VISUAL (CONGENITAL VISUAL IMPAIRMENT)
}

\author{
Siti Ina Savira \\ Psikologi, Fakultas Ilmu Pendidikan, Universitas Negeri Surabaya. \\ sitisavira@unesa.ac.id \\ Wagino \\ Pendidikan Luar Biasa, Fakultas Ilmu Pendidikan, Universitas Negeri Surabaya. \\ wagino@unesa.ac.id \\ Hermien Laksmiwati \\ Psikologi, Fakultas Ilmu Pendidikan, Universitas Negeri Surabaya. \\ hermienlaskmiwati@unesa.ac.id
}

\begin{abstract}
Abstrak
Penelitian ini bertujuan untuk mengetahui profil kognitif anak dan remaja tunanetra. Penelitian ini menggunakan metode sintesis riset (research synthesis). Sampel dalam penelitian ini merupakan 11 referensi ilmiah tentang ketunanetraan yang dianggap paling merepresentasikan fokus penelitian ini. Teknik pengumpulan data dilakukan dengan menggunakan mesin pencari daring, yaitu melalui scholar.google.com, dengan memasukkan kata kunci tertentu. Referensi ilmiah dipilih berdasarkan kesesuaian dengan kriteria dan batasan dalam penelitian ini. Variabel diidentifikasi berdasarkan fokus dari masing-masing referensi ilmiah, dengan asumsi bahwa referensi dari hasil penelitian memiliki fokus variabel tertentu yang diukur. Adapun 5 variabel tersebut adalah penalaran, ingatan, orientasi spasial, perbendaharaan kata, dan penalaran kata. Variabel, aspek, dan indikator diidentifikasi melalui reduksi dan diberi coding. Hasil penelitian ini dituangkan dalam bentuk matriks yang menggambarkan variabel, aspek, dan indikator kemampuan kognitif anak tunanetra.
\end{abstract}

Kata Kunci: Kemampuan Kognitif, Sintesis Riset, Tunanetra

\begin{abstract}
This study is aimed to obtain cognitive profile of children with congenital visual impairment. The method used is research synthesis. The sample in this study is 11 research-based references on visual impairment. The data is collected using online search engine that is google scholar using specific keywords. The references were chosen based on the relevance with criteria set up for this study. The variables in each articles were then identified assuming that there should be at least one variable in each research-based article. There were 5 variables identified that are reasoning, memory, spatial orientation, vocabulary, and verbal reasoning. Variables, aspects, and indicators were identified using reduction and coding. The result in this study is presented in a matrix consisting variable, aspects, and indicators of cognitive ability of children with visual impairment.
\end{abstract}

Keywords: Cognitive Ability, Research Synthesis, Visual Impairment 


\section{PENDAHULUAN}

Kondisi tunanetra menjadi salah satu perhatian khusus dalam upaya meningkatkan kualitas hidup anak dengan kebutuhan khsusus. Kondisi tunanetra dapat mengakibatkan berbagai keterbatasan yang menghambat perkembangan anak dibandingkan dengan anak-anak tanpa masalah penglihatan dalam usia yang sama. Data dari Pusat Kajian Disabilitas Universitas Indonesia pada tahun 2010, menyebutkan bahwa prevalensi tunanetra di Indonesia mencapai 20\% dari total penyandang disabilitas yang berada dalam rentang taraf perekonomian keluarga sangat miskin hingga hampir miskin (Irwanto et al., 2010). Akan tetapi, sumber yang sama menyebutkan bahwa data mengenai penyandang disabilitas di Indonesia mungkin telah mengandung bias, sebab hanya mencerminkan penduduk penyandang disabilitas yang masuk dalam kategori miskin. Jika memperhitungkan hal tersebut maka penduduk penyandang disabilitas bisa mencapai dua kali lipatnya (Irwanto et al., 2010), termasuk juga akan meningkatkan prevalensi penyandang tunanetra. Sebagai tambahan, (Garina, 2012) menyebutkan bahwa dari total penyandang cacat di Indonesia, sekitar $24,45 \%$ adalah anak-anak dan remaja berusia antara 0-18 tahun, dimana 21,42\% merupakan anak cacat usia sekolah. Walaupun data mengenai anak berkebutuhan khusus termasuk penyandang cacat, secara nasional belum dapat teridentifikasi dengan pasti (Garina, 2012) akan tetapi, gambaran umum tersebut cukup menunjukkan pentingnya memberi perhatian pada anak/remaja berkebutuhan khusus, termasuk tunanetra.

Visual impairment atau tunanetra merupakan segala bentuk berkurangnya kemampuan penglihatan (Gunaratne, 2002). Anak dengan kondisi tunanetra (low vision hingga total blindness) memiliki perbedaan dalam hal perkembangan dan keterampilan-keterampilan khusus. Beberapa perbedaan tersebut mencakup aspek-aspek seperti inteligensi dan penalaran (Smits and Mommers, 1976, Tobin and Hill, 2011), kemampuan imagery dan proses spasial (Cattaneo et al., 2008; Eardley \& Pring, 2007; Vecchi, Tinti, \& Cornoldi, 2004), keterampilan orientasi dan mobilitas (Tobin \& Hill, 2011), mengingat (Pring, 2008, Withagen et al., 2013), serta kemampuan belajar (Pring, 2008). Sumber lain juga menyatakan bahwa perkembangan kognitif anak tunanetra secara umum lebih terhambat dibandingkan dengan anak-anak normal pada umumnya (contohnya Somantri (2006).

Anak dengan kondisi tunanetra memiliki keterbatasan atau bahkan ketidakmampuan dalam menerima rangsangan atau informasi dari luar dirinya melalui indera penglihatannya. Dengan demikian, eksplorasi pada anak tunanetra dilakukan dengan mengoptimalkan indera-indera yang lain, seperti perabaan, suara, dan penciuman (Somantri, 2006). Akan tetapi, penelitian menunjukkan bahwa anak-anak dengan kekurangan penglihatan mengkompensasi kekurangan tersebut melalui indera yang lain, terutama pendengaran (Pring, 2008). Individu dengan kondisi tunanetra menyimpan ingatan dalam bentuk verbatim, yang menyebabkan kemampuan lebih baik dalam mendiskriminasi 
suara dibandingkan orang normal (Muchnik et al., 1991, Pring and Tadić, 2010), dan memproses kata-kata verbal lebih cepat dibandingkan orang yang memiliki penglihatan normal (Röder et al., 2000), serta memiliki kemampuan lokalisasi auditori (memperhatikan suara yang berada di ruang auditori peripheral) (Pring \& Tadic, 2010).

Secara teoritis, perkembangan kognitif menuntut partisipasi aktif, peran dan fungsi penglihatan sebagai saluran utama dalam melakukan pengamatan terhadap dunia luar (Solso, MacLin, \& MacLin, 2014). Salah satu akibatnya, anak tunanetra memiliki kecenderungan untuk menggunakan kata-kata tanpa memahami makna yang sebenarnya (Dokecki, 1966). Anak dengan kondisi tunanetra kerap mengalami masalah konseptualisasi yang abstrak, karena tidak atau kurang memiliki pandangan yang kongkrit dan fungsional (Somantri, 2007).

Lebih lanjut lagi, mengenai perkembangan bahasa pada anak tunanetra, berbagai hasil penelitian menunjukkan bahwa dibandingkan dengan anak yang memiliki penglihatan normal, kosakata anak tunanetra cenderung bersifat definitif (Dokecki, 1966). Selain itu, anak tunanetra kerap mendapat kesulitan dalam mengintegrasikan pengalaman yang dialami, sehingga sulit untuk dapat mengkonstruk atau menyimpulkan sendiri pengetahuan berdasarkan pengalaman yang dialami. Piaget (dalam Santrock (2011), menyebutkan bahwa perkembangan fungsi kognitif berlangsung mengikuti prinsip mencari keseimbangan melalui teknik asimilasi dan akomodasi. Kedua teknik tersebut dilakukan dengan mengintegrasikan pengetahuan yang diperoleh melalui pengalaman atau pengamatan terhadap lingkungan dengan pengetahuan yang telah dimiliki. Selain itu, salah satu yang secara dominan mempengaruhi pembentukan persepsi adalah stimulus yang masuk melalui indera penglihatan. Dengan demikian, pembentukan pengetahuan pada anak dengan kondisi tunanetra dapat mengalami hambatan.

Berdasarkan uraian di atas, dapat diketahui bahwa perkembangan kemampuan kognitif pada anak dengan kondisi tunanetra memiliki perbedaan dengan anak tanpa masalah penglihatan. Beberapa penelitian juga menunjukkan hasil yang kurang konsisten, sehingga dimungkinkan masih terdapat berbagai keyakinan yang salah atau belum terbukti mengenai kemampuan kognitif anak dengan masalah penglihatan (Power-deFur, L.A. ed., 2015). Sementara itu, kebutuhan untuk memiliki instrumen yang dapat memberikan gambaran lebih baik mengenai kemampuan kognitif anak tunanetra semakin dibutuhkan untuk dapat memenuhi kebutuhan pendidikannya (Wicaksono and Witoelar, 2019).

Dengan demikian, penelitian ini berupaya untuk mendapatkan pemahaman mengenai kemampuan kognitif anak dengan kondisi tunanetra dan selanjutnya diharapkan dapat dijadikan dasar penyusunan instrumen yang tepat yang dapat digunakan pada individu dengan ketunanetraan. 


\section{METODE}

Penelitian ini menggunakan metode sintesis riset (research synthesis). Sintesis riset merupakan metode sistematis untuk mereview dan mengintegrasikan berbagai kajian literatur pada area tertentu (Cooper and Valentine, 2008). Sumber yang sama menyebutkan langkah-langkah dalam metode sintesis riset adalah sebagai berikut; (1) merumuskan permasalahan; (2) pengajian literatur; (3) evaluasi data; (4) analisis dan interpretasi; (5) presentasi publik.

Persamaan dalam definisi konseptual sangat penting dalam penelitian sintesis riset, sehingga perlu mengkaji persamaan definisi tiap variabel penelitian yang dijelaskan secara definitif. Pemilihan referensi mengikuti kriteria berikut, (1) subyek penelitian merupakan subyek dalam kateori anak hingga remaja dengan rentang usia 0 hingga 13 tahun; (2) subyek penelitian memiliki kondisi congenital visual impairment sesuai definisi WHO mengenai visual impairment; (3) subyek penelitian tidak memiliki gangguan perkembangan lain yang teridentifikasi selain kondisi ketunanetraannya.

Teknik pengumpulan data dilakukan dengan melakukan kajian literatur menggunakan mesin pencari secara online yaitu melalui scholar.google.com. Kata kunci 'cognitive ability on children with visual impairment' dimasukkan ke scholar.google.com. Selanjutnya, kata kunci semakin dipersempit dengan variabel-variabel seperti reasoning, memory, spatial ability, dan lain-lain. Pada awalnya, target penelitian ini adalah 10 sumber ilmiah. Akan tetapi, dalam proses kajian literatur tersebut, ditemukan artikel yang mengacu pada artikel sebelumnya. Dengan pertimbangan untuk mendapatkan data yang lebih komprehensif, maka sumber lain tersebut perlu ditambahkan. Pada akhirnya, dilakukan analisis terhadap 13 artikel ilmiah yang terdiri dari artikel jurnal, proceeding, maupun book chapters. Sumber ilmiah tersebut adalah sebagai berikut; (1) Andersen et al. (1984); (2) Colom et al. (2002); (3) Vecchi et al. (2004); (4) Eardley and Pring (2007); (5) Pring (2008); (6) Cattaneo et al. (2008); (7) Andersen et al. (1993); (8) Lohman and Lakin (2009); (9) Pring and Tadić (2010); (10) Tadić et al. (2010); (11) Dale et al. (2014).

Adapun analisis dan interpretasi data akan dilakukan dengan cara melakukan coding terhadap kajian literatur 10 jurnal tersebut. Hasil pengkodean (coding) akan dikategorikan dan dianalisis secara kualitatif untuk merumuskan kemampuan kognitif pada anak dan remaja tunanetra. Berdasarkan analisis dari sumber-sumber ilmiah yang disebutkan di bagian metode artikel ini, maka di bagian pembahasan, akan diuraikan gambaran kemampuan kognitif menurut sumber-sumber tersebut.

\section{HASIL DAN PEMBAHASAN}




\section{Hasil}

Berdasarkan hasil analisis dan interpretasi terhadap pengajian jurnal ilmiah, maka disusunlah variabel, aspek dan indikator kedalam suatu matriks rekapitulasi. Coding diberikan terhadap variabel dan aspeknya.

Berikut adalah daftar coding yang digunakan dalam penelitian ini:

Tabel 1. Daftar coding yang digunakan dalam penelitian

\begin{tabular}{|c|c|c|}
\hline Variabel & Aspek & Indikator \\
\hline \multirow[t]{3}{*}{ Reasoning (Rs) } & Rs1 & Rs1.1 \\
\hline & Rs2 & Rs2.1 \\
\hline & Rs3 & Rs3.1 \\
\hline \multirow[t]{4}{*}{ Orientasi Spasial (Sp) } & Sp1 & Sp1.1 \\
\hline & Sp2 & Sp2.1 \\
\hline & Sp3 & Sp3.1, Sp3.2 \\
\hline & Sp4 & Sp4.1 \\
\hline \multirow[t]{3}{*}{ Ingatan (m) } & $\mathrm{m} 1$ & $\mathrm{~m} 1.1, \mathrm{~m} 1.2, \mathrm{~m} 1.3, \mathrm{~m} 1.4, \mathrm{~m} 1.5, \mathrm{~m} 1.6$ \\
\hline & $\mathrm{m} 2$ & $\mathrm{~m} 2.1, \mathrm{~m} 2.2$ \\
\hline & $\mathrm{m} 3$ & $\mathrm{~m} 3.1, \mathrm{~m} 3.2, \mathrm{~m} 3.3, \mathrm{~m} 3.4, \mathrm{~m} 3.5, \mathrm{~m} 3.6$ \\
\hline \multirow[t]{3}{*}{ Perbendaharaan kata (Vb) } & Vb1 & Vb1.1 \\
\hline & Vb2 & Vb2.1 \\
\hline & Vb3 & Vb3.1 \\
\hline \multirow[t]{3}{*}{ Penalaran verbal (VRs) } & VRs1 & VRs1.1, VRs1.2 \\
\hline & VRs2 & VRs2.1, VR2.2 \\
\hline & VRs3 & VRs3.1, VRs3.2, VRs3.3 \\
\hline
\end{tabular}

Variabel, aspek dan indikator diidentifikasi dari 10 jurnal yang disebutkan diatas. Definisi dari variabel dirumuskan setelah indikator dirinci. Adapun definisi variabel yang berhasil direduksi dari analisis kualitatif terhadap 10 jurnal tersebut adalah adalah sebagai berikut:

1. Reasoning (Rs) merupakan kemampuan menarik kesimpulan atau inferensi dari suatu informasi hingga melampaui informasi itu sendiri.

2. Orientasi Spasial (Sp) adalah kemampuan melakukan manipulasi, transformasi, dan integrasi informasi berdasarkan tingkat kesulitan atau kompleksitas obyek ( 2 dimensi atau 3 dimensi, bergerak atau tidak bergerak, serta jumlah atau banyaknya obyek/informasi). 
3. Ingatan (m) merupakan kemampuan melakukan tugas-tugas recall angka, kata, gambaran spasial dan mempertahankannya secara mental dalam waktu tertentu secara akurat.

4. Perbendaharaan kata $(\mathrm{Vb})$ adalah kemampuan individu untuk mempelajari dan memperkaya kosakata kata melalui kemampuan mengembangkan konteks penggunaan kata, dan fungsi kata untuk menjelaskan berbagai aktivitas dan kebutuhan diri sendiri dan orang lain.

5. Penalaran verbal (VRs) adalah kemampuan memahami makna bahasa, dan menggunakannya dalam konteks yang berbeda dan luas, serta kemampuan memahami pergantian perspektif dan berbagi perhatian dalam percakapan, dan menggunakan bahasa dalam percakapan dengan efektif.

Hasil penelitian ini diringkas dalam matriks berikut:

Tabel 2. Matriks Hasil Penelitian

\begin{tabular}{|c|c|c|c|c|}
\hline Variabel & jurnal & Coding & Coding & Indikator \\
\hline \multirow{3}{*}{ Rs } & \multirow[t]{2}{*}{$\# 8$} & Rs1 & Rs1.1 & $\begin{array}{l}\text { kemampuan untuk memilih apa yang perlu } \\
\text { diperhatikan dan mana yang perlu diabaikan }\end{array}$ \\
\hline & & Rs2 & Rs 2.1 & $\begin{array}{l}\text { kemampuan untuk menarik dan kemudian } \\
\text { membandingkan suatu informasi yang relevan dari } \\
\text { sebuah konsep yang berasal dari LTM }\end{array}$ \\
\hline & $\# 8$ & Rs3 & Rs3.1 & $\begin{array}{l}\text { kemampuan WM untuk mengatur secara strategis } \\
\text { proses mental dengan mengkombinasikan informasi }\end{array}$ \\
\hline \multirow[b]{5}{*}{$\mathrm{Sp}$} & \multirow{2}{*}{$\begin{array}{l}\# 2,6 \\
\# 2,4\end{array}$} & Sp1 & Sp1.1 & tingkat kesulitan \\
\hline & & $\mathrm{Sp} 2$ & Sp1.2 & kecepatan manipulasi pola visual \\
\hline & \multirow{3}{*}{$\begin{array}{l}\# 3,5,6 \\
\# 3,4,5,6\end{array}$} & \multirow[t]{2}{*}{ Sp3 } & Sp3.1 & $\begin{array}{l}\text { kecepatan imagery mental menggunakan beragam } \\
\text { modalitas sensori (auditori, haptic/perabaan, } \\
\text { kinestetik, penciuman, dan penglihatan) }\end{array}$ \\
\hline & & & Sp3.2 & $\begin{array}{l}\text { kemampuan manipulasi, transformasi, dan integrasi } \\
\text { informasi }\end{array}$ \\
\hline & & Sp4 & Sp4.1 & $\begin{array}{l}\text { kemampuan generalisasi imagery yang melibatkan } \\
\text { lebih dari } 1 \text { obyek dan } 1 \text { tempat }\end{array}$ \\
\hline \multirow[t]{3}{*}{$\mathrm{m}$} & \multirow{3}{*}{$\begin{array}{l}\# 3,4 \\
\# 3,4\end{array}$} & \multirow[t]{3}{*}{$\mathrm{m} 1$} & $\mathrm{~m} 1.1$ & kecepatan imagery gerakan konfigurasi 2D \\
\hline & & & $\mathrm{m} 1.2$ & kecepatan imagery gerakan konfigurasi 3D \\
\hline & & & $\mathrm{m} 1.3$ & kecepatan dalam memproses informasi spasial \\
\hline
\end{tabular}




\begin{tabular}{|c|c|c|c|c|}
\hline & \#3 & & $\mathrm{m} 1.4$ & $\begin{array}{l}\text { kemampuan merepresentasikan/mempertahankan } \\
\text { gambaran spasial dalam satu waktu yang bersamaan, } \\
\text { secara vertikal dan horisontal }\end{array}$ \\
\hline & $\# 3$ & & $\mathrm{~m} 1.5$ & $\begin{array}{l}\text { kemampuan merecall/mengingat } 1 \text { pola dalam waktu } \\
\text { yang sama }\end{array}$ \\
\hline & \#3 & & $\mathrm{m} 1.6$ & $\begin{array}{l}\text { kemampuan merecall/mengingat lebih dari } 1 \text { pola } \\
\text { dalam waktu yang sama }\end{array}$ \\
\hline & \#6 & $\mathrm{m} 2$ & $\mathrm{~m} 3.1$ & $\begin{array}{l}\text { kemampuan membedakan suara yang muncul pada } \\
\text { saat yang bersamaan }\end{array}$ \\
\hline & \#6 & & $\mathrm{m} 3.2$ & $\begin{array}{l}\text { kemampuan membedakan suara laki-laki dan } \\
\text { perempuan dari rekaman suara }\end{array}$ \\
\hline & & $\mathrm{m} 3$ & $\mathrm{~m} 4.1$ & kemampuan mengingat deret angka dalam digit span \\
\hline & $\# 5,6,9$ & & $\mathrm{~m} 4.2$ & $\begin{array}{l}\text { kemampuan melakukan tugas recall verbatim secara } \\
\text { akurat }\end{array}$ \\
\hline & & & $\mathrm{m} 4.3$ & kecepatan dalam memproses informasi verbal \\
\hline & \#5 & & $\mathrm{m} 4.4$ & $\begin{array}{l}\text { kemampuan melakukan tugas recall braille dan gambar } \\
\text { taktil secara akurat }\end{array}$ \\
\hline & $\# 5$ & & $\mathrm{~m} 4.5$ & $\begin{array}{l}\text { kemampuan mengingat secara semantik secara lebih } \\
\text { akurat (contoh mengingat nama) }\end{array}$ \\
\hline & $\# 5,6$ & & $\mathrm{~m} 4.5$ & $\begin{array}{l}\text { kemampuan dalam melakukan tugas recall kata dengan } \\
\text { akurat }\end{array}$ \\
\hline & \#7 & Vb1 & Vb1.1 & $\begin{array}{l}\text { kemampuan melakukan generalisasi konteks kata } \\
\text { dibandingkan saat kata tersebut pertama kali dipelajari }\end{array}$ \\
\hline & $\# 7$ & $\mathrm{Vb} 2$ & $\mathrm{Vb} 2.1$ & $\begin{array}{l}\text { kemampuan menggunakan kata untuk menjelaskan } \\
\text { berbagai aktivitas dan kebutuhan diri sendiri }\end{array}$ \\
\hline & $\# 7,9$ & Vb3 & Vb3.1 & $\begin{array}{l}\text { kemampuan membedakan obyek atau konsep secara } \\
\text { semantik }\end{array}$ \\
\hline $\mathrm{Vb}$ & $\# 9$ & & Vb3.2 & $\begin{array}{l}\text { Memahami makna abstrak seperti warna \& } \\
\text { menggunakannya dalam percakapan }\end{array}$ \\
\hline VRs & $\# 1,9$ & VRs1 & VRs1.1 & $\begin{array}{l}\text { kemampuan menggunakan kemampuan berbahasa } \\
\text { dalam percakapan }\end{array}$ \\
\hline
\end{tabular}




\begin{tabular}{|c|c|c|c|}
\hline$\# 1,5$ & & VR1.2 & $\begin{array}{l}\text { kemampuan menggunakan kemampuan berbahasa } \\
\text { dalam percakapan dengan pergantian perspektif dalam } \\
\text { menentukan makna kata }\end{array}$ \\
\hline$\# 1$ & VRs2 & VRs2.1 & $\begin{array}{l}\text { dapat menggunakan kata untuk konteks yang } \\
\text { khas/melekat pada diri sendiri (idiosyncratic) }\end{array}$ \\
\hline$\# 1,7$ & & VRs2.2 & $\begin{array}{l}\text { dapat menggunakan kata kerja terbatas untuk kegiatan } \\
\text { yang dilakukan diri sendiri }\end{array}$ \\
\hline $\begin{array}{l}\# 5,7,9,10, \\
11\end{array}$ & & VRs2.3 & $\begin{array}{l}\text { kemampuan memahami perasaan dan sudut pandang } \\
\text { orang lain melalui percakapan }\end{array}$ \\
\hline
\end{tabular}

Tabel di atas merupakan hasil reduksi dari 11 sumber ilmiah yang menjadi referensi utama dalam penelitian ini. Setelah variabel yang dianggap relevan dengan kemampuan kognitif teridentifikasi, selanjutnya adalah mencari aspek-aspek yang terdapat di dalam variabel tersebut. Langkah berikutnya adalah mencari bentuk operasional dari aspek yang telah ditemukan. Bentuk operasional yang dimaksud merupakan bentuk atau contoh perilaku yang dapat diamati atau mengandung unsur yang dapat diukur. Unsur yang dapat diukur misalnya berupa degree, frekuensi, atau kondisi kongkrit dan spesifik yang dapat diterjemahkan ke dalam tugas tertentu. Jika ditemukan beberapa bentuk operasional sebagai penjelasan dari aspek tertentu, maka semua didaftar dan dituliskan sebagai indikator. Jika indikator memiliki lebih dari satu penjelasan, maka penjelasan yang lebih spesifik dimasukkan dalam kolom di sebelah kiri dan disebut sebagai sub-indikator.

\section{Pembahasan}

Vecchi et al. (2004) menyebutkan bahwa anak tunanetra menunjukkan pola kinerja yang serupa dengan orang normal dalam tugas-tugas mental yang membutuhkan rotasi objek, penggunaan mnemonics imajeri dan ingatan konfigurasi spasial. Orang tunanetra kemungkinan menggunakan imaji mental dalam membuat asosiasi terhadap modalitas sensori selain penglihatan dengan keterlibatan area visual dan somatosensori. Tedapat tiga batasan imaji mental pada orang tunanetra, yaitu (1) proses imaji mental yang lambat, (2) kesulitan dalam menggenerasikan imaji secara interaktif yang melibatkan lebih dari 1 objek dan 1 tempat, (3) hambatan kinerja ketika diminta untuk membayangkan gerakan konfigurasi objek 3 dimensi daripada 2 dimensi.

Lebih lanjut lagi Vecchi et al. (2004) menduga bahwa 3 hambatan tersebut berkait dengan proses penyimpanan pasif dan aktif. Proses pasif adalah proses recall memori dalam format yang sama seperti format awal ingatan itu dibentuk, proses aktif membutuhkan manipulasi, transformasi atau integrasi informasi. Kondisi ini menimbulkan asumsi bahwa anak tunanetra seharusnya mengalami kesulitan dalam proses aktif. Kemungkinan lain, 3 hambatan tersebut berkaitan dengan: 
(1) tugas/permintaan untuk memperlakukan dan mempertahankan representasi visuo-spasial yang berbeda secara simultan, (2) Kesulitan yang akan menghasilkan ketidakmampuan untuk memproses informasi spasial secara cepat, (3) Untuk mempertahankan imaji dari beragam objek secara simultan dan untuk merepresentasikan gamabran spasial dalam satu waktu yang bersamaan, secara vertikal dan horisontal.

Penjelasan tentang kesulitan anak tunanetra untuk melakukan proses spasial secara simultan dalam working memory mereka berkaitan dengan pengalaman visual. Orang tunanetra mendapatkan informasi spasial dari gerakan dan eksplorasi taktil dalam bentuk sikuensial, sedangkan visual akan memberikan proses informasi yang simultan. keterbatasan proses simultan dapat menimbulkan kesulitan dalam memahami dan mempertahankan beragam imaji secara interaktif. Pada saat yang sama, proses kognitif terjadi lebih lambat ketika diminta melakukan elaborasi simultan dan pola 3 dimensi membutuhkan simpulan dan perlakuan lebih dari sebuah represenstasi 2 dimensi di saat yang sama.

Ketidakmampuan visual tidak pernah berasosiasi dengan gangguan sistem saraf pusat. Orang tunanetra dapat melakukan tugas visuo-spasial dalam working memory sebaik orang normal, tetapi tunanetra juga menunjukkan adanya keterbatasan yang spesifik. Orang tunanetra juga terbukti mampu melakukan proses imaji mental dalam matriks tunggal. Orang tunanetra sejak lahir (congenitally blind) dapat memproses dan mentransformasi imaji mental namun kesulitan dalam merecall lebih dari 1 pola dalam waktu yang sama.

Eardley and Pring (2007) menyebutkan bahwa informasi visual adalah hal dasar dalam proses spasial dan dalam membentuk proses mekanisme spasial. Ada 2 komponen proses spasial, yaitu aktif dan pasif. Proses spasial aktif terjadi ketika orang harus melakukan manipulasi atau mengorganisasikan kembali sebuah informasi atau mengkombinasikan dengan imaji yang berbeda dan serupa dengan "ïnner scribe”. Proses spasial pasif berusaha untuk mendapatkan informasi visuospasial tanpa memiliki kapasitas untuk melakukan modifikasi pada informasi tersebut dan serupa dengan "visual cache".

Informasi spasial diperlukan untuk mengenali sebuah objek yang dapat diproses dalam tugas yang mandiri dan tidak menggunakan suatu indera yang spesifik. Sintesa mental membutuhkan 3 hal, yaitu menipulasi bagian komponen, menggunakan imajeri/pembayangan, untuk memahami bentuk dasar. Proses ini terjadi dalam bentuk aktif dan pasif. Informasi spasial dapat diperoleh secara seimbang dari sumber non-visual (Eardley and Pring, 2007).

Kemampuan untuk menghasilkan sesuatu yang baru menggunakan imajeri adalah hal yang umum bagi individu tunanetra maupun normal. Proses spasial memiliki tugas yang signifikan dalam membuat bentuk baru menggunakan imajeri. tidak ada korelasi antara kemampuan verbal yang 
terukur dalam tugas kelancaran verbal dengan kinerja dalam sintesa mental, baik pada 2 dimensi maupun 3 dimensi, bagi tunanetra maupun yang bisa melihat.

Orang tunanetra kurang mampu menghasilkan representasi 2 dimensi dan 3 dimensi. Penelitian menunjukkan bahwa orang yang lahir tanpa penglihatan dapat menciptakan bentuk baru dalam 2 dimensi dan menggunakan imajeri saja. Individu yang buta total tidak fimiliar dengan konvensi dari representasi 2 dimensi dan kurang mendapat pengalaman langsung dari tipe represntasi ini. Hal ini bisa terjadi karena mereka kurang pengalaman dan familiar dengan media, daripada disebabkan oleh kekurangan dalam kapasitas sistem imajeri. Penglihatan bukanlah prasayarat untuk semua tugas spasial dan secara spesifik tidak diperlukan untuk adaptasi proses spasial aktif.

Menurut Pring (2008), menjelaskan bahwa salah satu hambatan perkembangan kognisi sosial pada orang tunanetra disebabkan karena kondisi ketunanetraan tersebut membatasi kesempatan untuk mengasosiasikan emosional dan kondisi mental dengan perilaku mereka. Hal ini membawa kita memprediksi bahwa anak dengan tunanetra atau VI (Visual Impairment) mengalami kesulitan dalam perkembangan Theory of Mind (ToM). Mayoritas anak dengan VI mengalami keterlambatan perkembangan ToM sampai usia 12 tahun. Cara utama agar anak dapat mengetahui pikiran orang lain hanya melalui bahasa. Bahasa dapat dilihat sebagai mekanisme berbagi perhatian. Peran percakapan sangat kritis untuk pemahaman sosial.

Dalam aspek memori, anak tunanetra menunjukkan tanda-tanda bahwa mereka memiliki ingatan yang sangat kuat, terutama dalam short term memory (STM), sebab memori mereka berkaitan langsung dengan situasi. Perhatian mereka meningkat terhadap beragam material yang kemungkinan disimpan lebih lama dalam bentuk "verbatim form", sebuah strategi memori yang kurang umum "digunakan" pada orang yang bisa melihat. Selain itu para tunanetra memiliki sumber informasi ekstra pada pendengaran sehingga dapat menjadi "seeing ear". Individu yang mengalami gangguan penglihatan berat sejak lahir (congenitally profound visual impairment) menunjukkan kemampuan untuk memproses wicara lebih cepat daripada orang yang bisa melihat. Mereka juga memiliki kemampuan membedakan suara dalam ruangan yang ramai lebih baik daripada orang yang bisa melihat (Pring, 2008).

Pring (2008) menjelaskan mengenai keunggulan memori orang dengan VI yaitu sebagai berikut; (1) mampu mengingat deret angka dalam digit span. Pembelajaran verbal bergantung pada "short-term working memory" yang menyimpan infromasi secara sikuen sehingga siap untuk di analisis secara semantik dan juga prosees mekanisme konseptual yang mengatur pengetahuan ke dalam LTM; (2) keunggulan dlm tugas pemahaman kata dalam bentuk asal (kemampuan literal dan inferensial). Pada tugas ini, menunjukkan kelebihan menggunakan materi verbal dan memori literal kata dasar (ingatan verbatim untuk teks) dapat di recall secara akurat; (3) mampu merecall kata-kata 
yang direkam secara auditori, huruf braille dan gambar taktil; (4) Kemampuan untuk mengenali "pitch" suara laki-laki dan perempuan dari sebuah rekaman suara; (5) Ingatan semantik yang lebih akurat. Partisipan penelitian yang tunanetra lebih mampu mengingat nama guru dan teman dari long term memory (LTM) semantik.

Berdasarkan 5 hal tersebut di atas, kita dapat melihat bahwa terdapat keunggulan memori dan sangat membantu orang dengan VI dalam segala situasi, namun kita belum bisa memastikan bagaimana cara untuk mengukurnya sebab recall yang akurat tidak sama dengan banyaknya pengetahuan intelektual yang dimiliki. Proses belajar, imajeri dan memori adalah 3 aspek yang perlu dipahami dengan baik dalam karakteristik psikologis dari orang-orang dengan VI Individu tunanetra seringkali menggunakan kode mental spasial untuk merepresentasikan pikiran dari sebuah spasial secara alami (seperti main catur).

Pertama, penggunaan spatial mental imagery. Penelitian yang menggunakan garis, gambar dan peta yang timbul (emboss) menunjukkan bahwa orang dengan VI berusaha untuk menggunakan strategi analisis per aspek secara spesifik daripada menggunakan pendekatan strategi global. Contohnya, anak tunanetra salah memahami gambar dari bunga dafodil dengan sikat gigi karena teksturnya sama (berbintil-bintil) atau tidak dapat membedakan jam tangan dengan jam biasa karena bentuknya yg lingkaran. Vecchi et al (2004) menemukan bahwa materi yang diterima secara sikuen lewat taktil/perabaan dapat diintegrasikan menadi sebuah representasi mental spasial yang stabil.

Kedua, Imajeri dan imajinasi. Individu yg lahir tanpa penglihatan dapat memahami materi lewat taktil perabaan an membentuk representasi mental spasial tetapi mereka memiliki hambatan dalam tugas imaji spasial aktif. Konsekuensinya mereka akan kesulitan untuk menciptakan bentuk baru hanya mengandalkan imajeri. Partisipan tunanetra secara signifikan menghasilkan bentuk 3 dimensi daripada 2 dimensi karena sudah terbiasa dengan materialnya. kemampuan untuk menghasilkan sesuatu yang baru menggunakan imaji/imajeri adalah hal yang biasa dilakukan oleh org yang lahir dengan dan/atau tanpa penglihatan.

Cattaneo et al. (2008) menjelaskan bahwa mental imajeri mencakup karakteristik beragam modalitas sensori (auditori, haptic/perabaan, kinestetik, penciuman dan penglihatan). Imajeri didefinisikan sebagai (a) melihat "mata" pikiran (b) memiliki sebuah gambaran dalam kepala seseorang. Visual imajeri dan persepsi visual memiliki mekanisme yang sama seperti yang tampak dalam level perilaku dan fungsional. Hal ini menimbulkan pertanyaan tentang mental imajeri pada individu yang tidak pernah melihat maupun yang penglihatannya berkurang.

Individu tunanetra memiliki mental imajeri, berikut hal yang mendukung: bagian area kortikal visual antara yang melayani imajeri visual dengan yang melayani persepsi visual tidak tumpang tindih/overlap sama sekali. Korteks visual utama yang ssangat penting dalam persepsi visual tidak 
secara langsung terlibat dalam imajeri mental visual pada individu dgn penglihatan. Imajeri visual tampaknya dimediasi oleh aktivasi dari jaringan subsistem spasial dan area visual yang lebih tinggi tingkatannya. Area kortikal visual dapat diaktivasi oleh objek yang disajikan melalui modalitas sensori non-visual. Pada kondisi gangguan visual berat, teradi fenomena pengorganisasian ulang secara kuat yang terjadi di dalam otak, sehingga area korteks pasti akan memproses informasi visual yang lebih besar melalui modalitas sensori lainnya. Imaji mental merupakan hasil akhir dari serangkaian proses konstruktif menggunakan sumber informasi yang berbeda daripada hanya sekedar salinan input perseptual.

Orang tunanetra cenderung memiliki memori yang superior untuk kata yang dapat dibayangkan secara konkrit daripada yang abstrak. Instruksi imajeri merupakan sarana untuk memanggil sebuah kata dalam otak, bagi individu tunanetra maupun yg bisa melihat. Performa yang sama dapat dicapai dalam tugas imajeri dengan menggunakan strategi kognitif yang berbeda, dimana ketiadaan penglihatan membuat tunanetra bergantung pada verbal/semantik, haptic/perabaan maupun representasi spasial. Representasi warna pada tunanetra juga di kategorikan dan diasosiasikan dengan pengetahuan abstrak. hal ini merefleksikan bahwa aitem yang dapat diimajinasikan tidak hanya serangkaian proses imajeri namun juga beragam proses semantik. tunanetra tidak terganggu oleh aktivasi dari gambara visual yang tidak relevan dalam proses penalaran, mereka bergantung pada representasi mental tipe non visual. Demikian juga, tidak ditemukan pada orang tunanetra, kondisi verbal yang mempengaruhi ilusi visual dalam imajeri (Cattaneo et al., 2008).

Strategi berdasarkan imajeri haptic merupakan strategi berdasarkan imajeri visual dalam beragam tugas kognitif. Strategi haptic akurat seperti strategi visual imajeri pada individu yang baru mengalami kebutaan. tunanetra dapat menggantikan keterbatasan visual dengan bergantung kepada pengalaman dari area sensori lainnya, yaitu pada level perseptual, dengan meningkatkan kapasitas auditori dan pada level kognitif yang lebih tinggi dengan cara mengembangkan jaringan melalui akustik dan titik-titik taktil. Orang tunanetra menunjukkan performa superior jika dibandingkan dengan orang yang bisa melihat dalam auditory digit task, word span test dan pada LTM untuk materi suara dan verbal. Congenitally blind memiliki ketajaman taktil yang superior dan kemampuan lokalisasi auditori daripada orang yg bisa melihat. Lokalisasinya dapat spesifik untuk track/rute "dimana" dan "apa".

Proses auditori memperkuat track "dimana". Namun orang tunanetra sangat lambat dalam membedakan frekuensi dari target ("what" track) tunanetra dan orang yang bisa melihat punya perilaku sama dalam tugas perbandingan numerik menggunakan modalitas auditori. Invidu tunanetra menunjukkan beberapa hal dasar dari representasi angka secara umum, seperti (1) the "distance" effect: waktu reaksi yang lama ketika mendiskriminasikan konsep numerik, membandingkan jarak 
yang dekat dan jauh; (2) the "SNARC" effect: respon terhadap deret angka yang kecil lebih cepat dari sisi kiri sedangkan merespon angka yang lebih besar lebih cepat dari sisi kanan; (3) the obedience to Weber's law: dengan meningkatkan magnitudo target, proses numerik menjadi lebih tidak akurat. Semua hal tersebut menunjukkan bahwa representasi numerik secara semantik dapat berkembang dalam format spasial meskipun dalam kondisi tanpa ada visual. Ketiadaan penglihatan sejak lahir tidak mencegah atau menghambat perkembangan kontinuum mental dari arah kiri ke kanan sebagai representasi angka kecil ke besar.

Adapun mengenai kognisi spasial pada individu yang buta sejak lahir Cattaneo et al. (2008) menjelaskan bahwa ketiadaan penglihatan tidak berarti pengetahuan spasial benar-benar tidak ada. Meskipun orang tunanetra harus bergantung sepenuhnya pada auditori dan petunjuk haptic untuk mengaktivasi konsep spasial, mereka dapat menunjukkan kinerja yang sama atau bahkan lebih baik dari individu normal yang ditutup matanya dalam berbagai tugas spasial. Meski demikian, mempelajari sensoris pengganti tidak selalu cukup untuk mencapai level normal performa dalam tugas spasial. Congenital blind ternyata kesulitan untuk melakukan update spasial secara haptic pada gambar ketika mereka bergerak mengikuti gambar. Hal ini menunjukkan pentingnya pengalaman visual dalam pemahaman spasial.

Orang tunanetra dapat menunjukkan performa yang lebih baik setelah mendengar deskripsi "rute" daripada "survey" ketika ditemukan pola yang berlawanan arah. Eksplorasi yang lebih dalam pada peta taktil (bukan deskripsi verbal dari sebuah rute) dapat memfasilitasi orientasi dan mobilitas tunanetra dalam sebuah lingkungan. tunanetra dapat menggunakan perspektif aerial ataupun deskripsi "survey" untuk melakukan transformasi skala dan mentranslasikan hubungan 2 dimensi menjadi 3 dimensi dalam ruang nyata. tunanetra tidak memiliki strategi eksplorasi yang bagus sebab tipe eksplorasi mereka yang terbatas cenderung bergantung pada pengalaman mereka sendiri dan egosentris.

Faktor-faktor yang menyebabkan keragaman hasil penelitian tentang orientasi spasial antara lain familiaritas yang berbeda terhadap tugas \& kapasitas penggunaan strategi imajeri visual untuk menyelesaikan tuntutan tugas, kesulitan menyimpulkan tugas yang diminta, tipe respon yang diminta adalah estimasi jarak dan arah, sesuai dengan keterampilan mobilitas yang berbeda pada tiap partisipan penelitian, dan tipe lingkungan dan latihan. Akan tetapi, terdapat beberapa batasan dalam proses imajeri pada orang tunanetra, yaitu disebabkan oleh input haptic atau strategi non-visual lainnya yang menyebabkan representasi spasial yang berbeda dibanding dengan partisipan yang mendapat dukungan input visual. Orang tunanetra bergantung pada deskripsi verbal/preposisional dalam menunjukkan tugas imajeri spasial. 
Orang dengan kebutaan awal, menggunakan encoding lokasi yang relevan dalam sistem koordinat XY tanpa representasi visual. Orang tunanetra cenderung membuat dan mengingat analogi (non proposisional) representasi dari objek sebanyak individu yang bisa melihat. Orang tunanetra bisa menyelesaikan tugas rotasi mental dari serangkaian stimuli yang familiar secara akurat dan cepat, contoh memahami huruf braille. Namun saat diminta secara haptic untuk mengenali satu seri huruf alfabet, mereka tidak mampu. ketika familiaritas stimulus tes dikontrol, keterampilan haptic tunanetra berkembang seperti keterampilan visual orang normal.

Orang tunanetra punya batasan dalam tugas imajeri di sikuen alami pada pengalaman persepsi taktil. Hal ini disebabkan persepsi haptic dan auditori bergantung pada proses sikuensial. Oleh sebab itu, tampaknya orang dengan congenitally blind tidak mengembangkan proses yang efisien untuk mengatasi informasi yang sangat banyak secara simultan (keterabtasan proses). Sikuens alami dari pengalaman haptic mungkin merupakan faktor kritis dalam menentukan perbedaan antara sentuhan dan penglihatan saat mengenali tugas serta kemungkinan berada pada level kognitif tertinggi. Hambatan lain yang teramati pada tunanetra berkaitan dengan kemampuan imajeri ketika mereka diminta untuk membayangkan sebuah rute/track sepanjang matiks 3 dimensi. Hal tersebut disebabkan oleh adanya penurunan kemampuan dalam memperbarui gerakan track dalam 3 dimensi, perseptual atribut dari konfigurasi 3 dimensi (misal; jumlah sudut), karakteristik spesifik dari dimensi vertikal dan hilangnya pengalaman visual pada objek 3 dimensi (Cattaneo et al., 2008).

Andersen et al. (1993) menjelaskan mengenai perbedaan perolehan (akuisisi) bahasa pada orang tunanetra. Penguasaan makna semantik kata-kata awal yang didapatkan anak tunanetra hampir sama dengan anak normal, dimana kata yang paling sering diucapkan adalah kata benda (objek) dan orang, diikuti expresi wajah dan kata kerja. Analisis proses perkembangan leksikal anak tunanetra terbatas dalam memaknai sebuah kata dan sering tidak berkembang ke referensi baru. Sekitar 65\%-75\% makna kata dari 100 kata masih terikat dengan konteks awal yang digunakan selama periode kata tunggal. Anak tunanetra menunjukkan periode yang lebih lama dalam referensi kata satu-satu (isomorfisme) dan anak tunanetra memperlakukan kata seperti nama depannya sendiri (diperlakukan seolah kata tersebut spesifik untuk dirinya). Hal ini menunjukkan bahwa anak tunanetra yang masih kecil tidak menyusun hipotesis tentang lingkungan dan tidak menyusun makna kata selevel anak normal.

Anak tunanetra kesulitan melakukan pemilahan dan klasifikasi, meski mereka dapat contoh yang sama dengan anak normal. Strategi melakukan klasifikasi diajarkan dibawah kategori leksikal. Perkembangan leksikal pada anak tunanetra mungkin diakibatkan oleh kelambatan dalam kognisisensori motorik. Hal yang relevan dengan awal semantik adalah periode penting yang berkaitan dengan periode 2 sampai 3 kata. Anak tunanetra mulai menggabungkan kata dan mengekspresikan 
berbagai peran semantik pada waktu yang hampir sama dengan teman sebaya yang normal dan terlepas dari perkembangan leksikal mereka yang terbatas. Anak tunanetra menggunakan dirinya sendiri sebagai acuan dalam menggunakan sebuah kata, untuk menjelaskan perilaku mereka sendiri. Mereka jarang mengekspresikan deskripsi informasi, sedangkan anak normal tampak membicarakan kata baru. Konstruksi bahasa yang kompleks pada anak tunanetra mengacu pada kejadian masa lampau atau yang sudah terjadi.

Adapun penguasaan morfologi (ilmu bentuk kata yang mengidentifikasi satuan dasar bahasa sebagai satuan gramatikal), anak tunanetra memiliki perbedaan perkembangan morfologi bahasa Inggris dengan anak yang bisa melihat. Perkembangan morfologi diperoleh dengan mempelajari seluk beluk bentuk kata serta pengaruh perubahan bentuk kata terhadap golongan dan arti kata. Hal yang paling beda adalah "language-cognition interplay" meliputi bentuk past tense \& preposisi lokasi (in, out, on, dan sebagainya). Regular past tense ditengarai sebagai morfem pertama yang diketahui berbicara dengan lawan bicara, merupakan dasar keberhasilan dalam berkomunikasi sebab event "here \& now" mungkin tidak dibagi dengan lawan bicara atau dipahami secara beda oleh anak tunanetra (Andersen et al., 1993).

Strategi menggunakan past tense merupakan usaha anak tunanetra untuk beradaptasi terhadap kesalahpahaman tentang konteks "present" sebab bentuk kalimat lampau (past) lebih pasti daripada present bagi anak tunanetra ketika harus memilih topik dalam percakapan. Perbedaan perkembangan morfem antara anak tunanetra dengan anak normal mencakup istilah lokasi "di dalam" dan "di atas". Ketika kata keterangan tempat sering di gunakan sebagai kata kerja (verb), misalkan "put on your shoes" ketika kemampuan bahasa anak tunanetra berkembang maka penggunaan yang tidak lazim akan bisa terjadi. anak tunanetra lebih paham konsep "time before space" daripada konsep "space before time" ketiadaan visual menyulitkan tunanetra mengakses info lokasi.

Perkembangan pragmatis dalam ilmu bahasa memungkinkan individu untuk mempelajari pemakaian bahasa dikaitkan dengan konteks pemakaiannya, berkaitan dengan maksud pembicara, konteks dan keadaan. Keterampilan pragmatik anak tunanetra juga terdampak oleh ketiadaan visual, kesulitannya antara lain memulai \& mempertahankan topik, menciptakan diskusi yang koheren dan kohesif terutama saat ada kata atau ekspresi yang punya arti tersendiri dalam konteks yang digunakan, contoh: di sini, di situ, di sana, ini, itu. Saat percakapan antar anak tunanetra maupun dengan anak normal, satu hal yang paling sering hilang adalah keterampilan mengambil perspektif orang lain. Dunlea and Andersen (1992) menduga hal ini berkaitan dengan keterlambatan dalam perkembangan dari tahap bermain representasi bagi anak tunanetra. Jika dibandingkan dengan anak yang bisa melihat mampu mengeksplorasi beragam perspektif dan berlatih dalam berganti peran. 
Simpulan dari temuan pada perkembangan awal adalah bahwa ketiadaan visual membuat anak lebih kesulitan memahami objek dan orang, aktivitas serta hubungan yang mungkin terjadi diantara ketiganya. Hal ini tidak saja mempengaruhi pilihan topik percakapan tetapi tampaknya juga berdampak pada penguasaan bahasa secara general dan bagaimana cara kerjanya. di awal tahap perkembangan bahasa menunjukkan adanya elasi hambatan/ketiadaan kreatifitas yang diinisiasi oleh anak tunanetra serta inovasi seperti kualitas dari egosentrisitas dan bukti bahwa anak tunanetra tidak membangun bahasa secara aktif (Andersen et al., 1984, Andersen et al., 1993).

Penting untuk mengeksplorasi keluasan input verbal secara natural pada anak tunanetra yang dapat berpengaruh terhadap perkembangan bahasanya. Peran visual dalam interaksi awal secara umum adalah sebagai berikut, (1) visual mengarahkan perhatian anak ke orang lain, benda dan kejadian; (2) Sangat penting untuk melakukan koordinasi atensi antara orangtua dengan anak. Anak sangat sensitif terhadap ekspresi wajah dari pengasuh dan tatapan mata bayi ke ibu merupakan bentuk respon verbal; (3) Seringkali membatasi konten bahasa yang ditujukan kepada anak, (4) Visual merupakan informasi fundamental yang biasa digunakan anak saat mulai memproses klasifikasi objek, orang, kejadian dan mulai memetakan pengetahuan ini ke dalam bentuk linguistik sembari mereka aktif mengkonstruksi makna kata. Bahkan sebelum anak bisa bicara, orang dewasa menginterpretasikan perilaku yang dapat dipahami secara visual (menunjuk, menggapai) sebagai hal yang bermakna sehingga hal ini menjadi kesempatan bagi anak untuk belajar bagaimana perilaku \& vokalisasi dapat menyampaikan pesan (Dunlea and Andersen, 1992, Andersen et al., 1993).

Ketika anak semakin intens berkomunikasi, mereka sangat bergantung pada gesture dan gerakan mata (eye gaze), awalnya hanya untuk menarik dan mengarahkan perhatian pada partner bicara yang disebut "joint attention". Berikutnya mereka akan menggunakan hal tersebut untuk membangun hubungan yang lebih kompleks termasuk untuk memberi dan menerima informasi. Pengasuh berkonsentrasi terhadap input verbal (bahasa yang mereka tujukan kepada anak) hampir khusus pada bahasan apa yang anak suka sebagai naluri memperbolehkan anak menentukan topik. Ketika pengasuh mengenalkan topik baru, mereka menggunakan dukungan gesture (misalkan menunjuk) kemudian mengamati gerakan mata dan fisik anak untuk meyakinkan apakah anak paham dengan topik diskusi.

Orang tunanetra tidak melakukan gesture secara spontan tetapi harus diajarkan stimuli dari modalitas lain (selain visual) tidak serta merta mencetuskan perilaku ini. Adapun 4 area analisis pada anak tunanetra adalah proporsi berbagai tipe kalimat, tipe perilaku berbicara, penggunaan label versus atribusi, dan frekuensi dari tipe topik yang berbeda. Hasil menunjukkan bahwa tidak ada perbedaan signifikan pada frekuensi dari beragam tipe kalimat yang ditujukan pada tunanetra ketika usia 1,4 1,6 tahun (periode 1) \& 1,8-1,10 (periode 2), mereka lebih sedikit mendapatkan kalimat deklaratif 
daripada anak normal. Kalimat yang paling sering diterima oleh anak tunanetra adalah kalimat imperatif. untuk pertanyaan "ya-tidak" dan pertanyaan "Wh..." tidak terlalu besar bedanya pada anak tunanetra dibanding anak normal selama 6 bulan. terjadinya peningkatan pertanyaan "Wh..." benarbenar meningkat pada anak tunanetra $(+/-8 \%)$ seiring penyesuaian secara verbal dan bisa menjawab pertanyaan (Andersen et al., 1984).

Proporsi yang besar dari kalimat imperatif dan pertanyaan yang meminta tindakan pada anak tunanetra disebabkan oleh 2 faktor, yaitu kelambatan perkembangan lokomotor, dan kelambatan tunanetra dalam menginisiasi aktivitas dan topik. Tanpa usaha untuk menggapai objek yang menarik maka tunanetra butuh intervensi/bantuan dari pengasuh mereka. Meski mereka sudah bisa bergerak (mobile) mereka tidak selalu mampu menemukan mainan \& aktivitas yang tepat untuk menstimulasi perkembangan. Anak tunanetra cenderung di "bombardir" dengan label yang diulang-ulang daripada dapat info yang kaya tentang lingkungannya. Keberadaan info visual yang dapat dibuktikan menyulitkan pengasuh untuk mendeskripsikan sesuatu dan memulai percakapan secara alami/natural dengan anak tunanetra (Andersen et al., 1993)

Andersen et al. (1993) mengungkap bahwa ibu dari anak tunanetra menginisiasi topik dalam proporsi lebih tinggi, yaitu sebanyak 89\%-94\% dari waktu ketika anak mereka berusai 16 bulan. Lebih dari itu, meskipun anak tunanetra menjadi lebih aktif dalam menentukan fokus timbal balik (dalam percakapan) selama 5 bulan berikutnya, ibunya melanjutkan mengontrol pemilihan topik dalam presentase yang lebih tinggi. Pada pemeriksaan subjek "child-centered vs environment related vs displaced" data menunjukkan bahwa ibu dari anak tunanetra melakukan inisiasi topik yang lebih tinggi proporsinya daripada ibu dari anak normal. Topik pembicaraan pada anak tunanetra (16-22 bln) yang paling sering dibicarakan adalah (a) dirinya (child-centered), (b) topik yang berkaitan dengan lingkungan. Topik saat ini (now-here-and now) menjadi jarang. Pada anak periode 1, menerima topik berkaitan dengan lingkungan dan jumlahnya bertambah pada periode 2. Input bahasa pada anak tunanetra lebih "mengarahkan" dan struktrunya untuk menyemangati mereka agar berperan lebih aktif dalam percakapan maupun dalam lingkungan. Ibu anak tunanetra berperan dominan dalam menginisiasi dan mengatur topik yang cenderung "child-centered" dan melakukan pengulangan (repetisi) sebab anak tunanetra kehilangan makna kata pada usia 16-22 bulan digunakan untuk menarik perhatian dan mengarahkan perhatian partner untuk mengubah minat.

\section{KESIMPULAN}

Berdasarkan analisis terhadap jurnal ilmiah mengenai berbagai aspek dalam profil kognitif anak tunanetra, dapat disimpulkan bahwa perkembangan kognitif anak tanpa penglihatan visual secara umum sama dengan anak berpenglihatan normal. Akan tetapi, terdapat beberapa perbedaan dalam 
cara mereka melakukan pemrosesan informasi, mulai dari input, pengelolaan dan manipulasi informasi, serta mengekspresikan hasil pemrosesan informasi tersebut. Anak tunanetra dikatakan memiliki keunggulan dalam hal kinerja short term memory, sebab memiliki kemampuan yang lebih dalam menggunakan strategi informasi dalam bentuk verbal, tetapi mengalami keterlambatan dalam penguasaan makna semantic dan pragmatis dari penggunaan bahasa. Mereka juga lebih unggul dalam hal diskriminasi suara, pitch tone, dan secara lebih akurat mengingat informasi verbal.

Anak tunanetra juga memiliki hambatan dalam melakukan transformasi dan manipulasi obyek 3 dimensi dibandingkan 2 dimensi, yang diakibatkan oleh kesulitan dalam mempertahankan informasi dalam bentuk imajery dalam waktu yang cukup lama. Dalam komunikasi, mereka memiliki hambatan dalam menguasai theory of the mind, yang menyebabkan kesulitan dalam memahami sudut pandang orang lain dalam melakukan komunikasi sosial, melakukan taking turn dalam percakapan, dan menggunakan kata-kata dalam konteks yang tepat.

Penelitian ini berhasil merangkum kemampuan kognitif anak dan remaja tunanetra mencakup aspek-aspek reasoning (penalaran), orientasi spasial, ingatan, perbendaharaan kata, dan penalaran verbal. Adapun aspek-aspek tersebut didefinisikan sebagai berikut, (1) Reasoning (Rs) merupakan kemampuan menarik kesimpulan atau inferensi dari suatu informasi hingga melampaui informasi itu sendiri; (2) Orientasi Spasial (Sp) adalah kemampuan melakukan manipulasi, transformasi, dan integrasi informasi berdasarkan tingkat kesulitan atau kompleksitas obyek ( 2 dimensi atau 3 dimensi, bergerak atau tidak bergerak, serta jumlah atau banyaknya obyek/informasi); (3) Ingatan (m) merupakan kemampuan melakukan tugas-tugas recall angka, kata, gambaran spasial dan mempertahankannya secara mental dalam waktu tertentu secara akurat; (4) Perbendaharaan kata (Vb) adalah kemampuan individu untuk mempelajari dan memperkaya kosakata kata melalui kemampuan mengembangkan konteks penggunaan kata, dan fungsi kata untuk menjelaskan berbagai aktivitas dan kebutuhan diri sendiri dan orang lain; (5) Penalaran verbal (VRs) adalah kemampuan memahami makna bahasa, dan menggunakannya dalam konteks yang berbeda dan luas, serta kemampuan memahami pergantian perspektif dan berbagi perhatian dalam percakapan, dan menggunakan bahasa dalam percakapan dengan efektif.

\section{DAFTAR PUSTAKA}

Andersen, E.S., Dunlea, A. and Kekelis, L., 1993. The impact of input: Language acquisition in the visually impaired. First language, 13(37), pp.23-49.

Andersen, E.S., Dunlea, A. and Kekelis, L.S., 1984. Blind children's language: Resolving some differences. Journal of Child language, 11(3), pp.645-664. 
Cattaneo, Z., Vecchi, T., Cornoldi, C., Mammarella, I., Bonino, D., Ricciardi, E. and Pietrini, P., 2008. Imagery and spatial processes in blindness and visual impairment. Neuroscience \& Biobehavioral Reviews, 32(8), pp.1346-1360.

Colom, R., Contreras, M.J., Botella, J., \& Santacreu, J. 2002. Vehicles of spatial ability. Personality and Individual Differences, 32(5), 903-912.

Valentine, J.C. and Cooper, H., 2008. Research Synthesis and Meta-Analysis. In Handbook of Research on Adult Learning and Development (pp. 184-202). Routledge.

Dale, N.J., Tadić, V. and Sonksen, P., 2014. Social communicative variation in 1-3 - year - olds with severe visual impairment. Child: care, health and development, 40(2), pp.158-164.

Dokecki, P.R., 1966. Verbalism and the blind: A critical review of the concept and the literature. Exceptional Children, 32(8), pp.525-530.

Dunlea, A. and Andersen, E.S., 1992. The emergence process: Conceptual and linguistic influences on morphological development. First Language, 12(34), pp.95-115.

Power-deFur, L.A. ed., 2015. Common Core state standards and the speech-language pathologist: Standards-based intervention for special populations. Plural Publishing.

Eardley, A.F., \& Pring, L. 2007. Spatial processing, mental imagery, and creativity in individuals with and without sight. European Journal of Cognitive Psychology, 19(1), 37-58.

Garina, L.A. 2012. Prevalensi, karakteristik, dan pelayanan kesehatan bagi anak berkebutuhan khusus di Indonesia.

Gunaratne, L.A. 2002. Visual impairment: Its effect on cognitive development and behaviour: Intellectual Disability and Health. University of Hertfordshire.

Irwanto, E.R.K., Fransiska, A., Lusli, M., \& Okta, S. 2010. Analisis situasi penyandang disabilitas di Indonesia: Sebuah desk-review. Pusat kajian disabilitas Fakultas ilmu-ilmu Sosial dan Politik. Universitas Indonesia. AusAID. Depok.

Lohman, D.F., \& Lakin, J.M. 2009. Reasoning and intelligence. Handbook of intelligence, 1-47.

Muchnik, C., Efrati, M., Nemeth, E., Malin, M., \& Hildesheimer, M. 1991. Central auditory skills in blind and sighted subjects. Scandinavian audiology, 20(1), 19-23.

Pring, L. 2008. Psychological characteristics of children with visual impairments: Learning, memory and imagery. British Journal of Visual Impairment, 26(2), 159-169.

Pring, L., \& Tadić, V. 2010. Cognitive and behavioural manifestations of blindness.

Röder, B., Rösler, F., \& Neville, H.J. 2000. Event-related potentials during auditory language processing in congenitally blind and sighted people. Neuropsychologia, 38(11), 1482-1502. 
Santrock, J.W., 2011. Life-span development 13th edition. New York: McGraw-Hill. Schunk, DH (2005). Self-regulated learning: The educational legacy of Paul R. Pintrich. Educational Psychologist, 40(2), pp.85-94.

Smits, B. W., and M. J. Mommers. "Differences between blind and sighted children on WISC verbal subtests." New Outlook for the Blind (1976).

Somantri, S., 2006. Psikologi anak luar biasa. Bandung: Refika Aditama.

Tadić, V., Pring, L. and Dale, N., 2010. Are language and social communication intact in children with congenital visual impairment at school age?. Journal of Child Psychology and Psychiatry, 51(6), pp.696-705.

Tobin, M.J. and Hill, E.W., 2011. Issues in the educational, psychological assessment of visually impaired children: Test-retest reliability of the Williams Intelligence Test for Children with Defective Vision. British Journal of Visual Impairment, 29(3), pp.208-214.

Vecchi, T., Tinti, C. and Cornoldi, C., 2004. Spatial memory and integration processes in congenital blindness. Neuroreport, 15(18), pp.2787-2790.

Wicaksono, T.Y. and Witoelar, F., 2019. Early Experience and Later Outcomes of Education: Schooling Transition Evidence from Indonesia. Bulletin of Indonesian Economic Studies, 55(1), pp.29-60.

Withagen, A., Kappers, A.M., Vervloed, M.P., Knoors, H. and Verhoeven, L., 2013. Short term memory and working memory in blind versus sighted children. Research in developmental disabilities, 34(7), pp.2161-2172. 